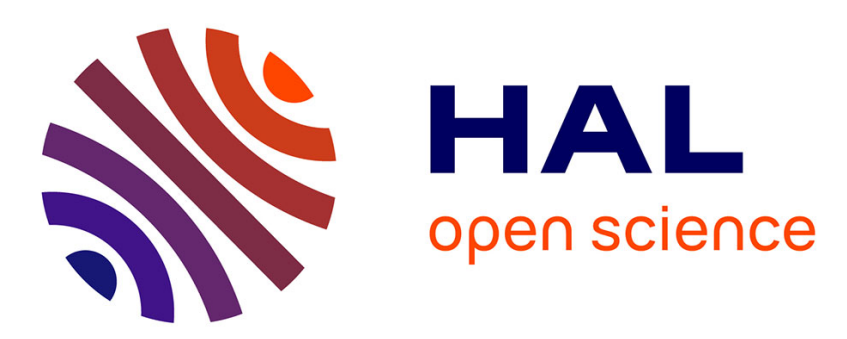

\title{
Bees in the Southwest Pacific: Origins, diversity and conservation
}

\author{
Scott Groom, Michael Schwarz
}

\section{To cite this version:}

Scott Groom, Michael Schwarz. Bees in the Southwest Pacific: Origins, diversity and conservation. Apidologie, 2011, 42 (6), pp.759-770. 10.1007/s13592-011-0079-8 . hal-01003616

\section{HAL Id: hal-01003616 https://hal.science/hal-01003616}

Submitted on 1 Jan 2011

HAL is a multi-disciplinary open access archive for the deposit and dissemination of scientific research documents, whether they are published or not. The documents may come from teaching and research institutions in France or abroad, or from public or private research centers.
L'archive ouverte pluridisciplinaire HAL, est destinée au dépôt et à la diffusion de documents scientifiques de niveau recherche, publiés ou non, émanant des établissements d'enseignement et de recherche français ou étrangers, des laboratoires publics ou privés. 


\title{
Bees in the Southwest Pacific: Origins, diversity and conservation
}

\author{
Scott V. C. Groom, Michael P. Schwarz \\ School of Biological Sciences, Flinders University, GPO Box 2100, Adelaide, SA 5001, Australia
}

Received 20 December 2010 - Revised 4 May 2011 - Accepted 9 May 2011

\begin{abstract}
Bee diversity of the Southwest Pacific has been reported as depauperate despite the otherwise rich biodiversity and complex geological history for this region. However, due to a lack of bee-specific sampling, there is potential for higher bee diversity than previous studies suggest. Here, we review the current literature to summarise the extant diversity for each of the main island groups, the likely passages of species dispersal, and outline the main threats to Southwest Pacific populations. As key pollinators for both cultivated and native angiosperms, ensuring the persistence of native bee populations is critical for both food security and biodiversity conservation. With impending threats from land use change, invasive species and climate change, among others, understanding the true species diversity is important for assigning conservation priorities. We argue that future research in the region must encourage local expertise and build this into global research directions in an effort to address a lack of fundamental knowledge of bee diversity in island ecosystems.
\end{abstract}

bees / conservation / biodiversity / biogeography / Pacific

\section{INTRODUCTION}

There is a broad array of challenges for understanding bee diversity and evolution in the Southwest Pacific (SWP) region. These challenges result from a confluence of three factors: (1) the lack of detailed field sampling that would allow true bee diversity to be reliably documented; (2) a lack of taxonomic revisions for many key island faunas so that identification of species, and the distributional extent of species, is poorly known; and (3) the highly variable geological history among SWP islands, ranging from Gondwanan elements through to comparatively recent subaerial origins, providing potentially fascinating insights into the

Corresponding author: S.V.C. Groom, scott.groom@flinders.edu.au

Manuscript editor: Stan Schneider genesis of island biota resulting from vicariance and dispersal.

In this review, we summarise the current knowledge of bee taxonomy and diversity in the SWP. Moreover, we outline the major vicariance and dispersal hypotheses for origins of the SWP biota and combine these two research areas to suggest how future bee studies may help understand how SWP bee fauna arose and how island ecologies may have been influenced. We finish by considering conservation issues surrounding endemic bees in the SWP and their potential importance for pollination of both agricultural crops and non-crop endemic plants.

\section{DIVERSITY AND TAXONOMY OF NATIVE BEES IN THE SOUTHWEST PACIFIC}

The bee fauna of the SWP has been the subject of a number of descriptive studies 
beginning with Smith (1879, 1953), Kohl (1908), Friese (1909) and, most recently, Pauly and Villemant (2009). Although these studies have resulted in a moderate number of species descriptions, many taxonomic assignments were not well determined and have required numerous revisions (Michener 1965). However, these revisions have often been regionally restricted. The only taxonomic revisions of SWP bees that provide identification keys for a region's bee fauna are for Halictinae in Vanuatu (Perkins and Cheesman 1939), Micronesia (Krombein 1950) and the Solomon Islands (Krombein 1951), along with Homalictus in Fiji (Michener 1979b) and New Guinea (Pauly 1986). These studies were not based on material from intensive bee-focussed regional sampling, nor did they entail methodologies that demonstrated species delimitation among islands other than through gross morphology entailing small sample sizes. Our understanding of bee diversity in the SWP is therefore very limited.

The composition of bee diversity in the SWP may be very important for understanding the roles of dispersal and vicariance in the assemblage of island bee faunas and how these may interact with insect-pollinated angiosperm communities. Studies to date suggest a generally low level of bee diversity in the SWP, though these studies do not indicate the reasons for this low diversity. The change in species representation of bee families across the SWP, illustrated in Figure 1, provides some very interesting patterns. Moving eastwards from Australia, Colletidae representation declines whilst the proportion of Halictidae and Megachilidae species increases. Moreover, Vanuatu has no representatives of Apidae and Colletidae despite their presence in neighbouring island groups. The species composition of each major island group is summarised below and tabulated in Table I.

\subsection{Australia and New Zealand}

Of the 1,650 named species of Australian bees (Batley and Hogendoorn 2009), over half (879 species) are represented by the Colletidae, a situation very unlike anywhere else in the world and one that led Michener (1965) to claim that Australia has the most unusual bee fauna of any continent in the world. Of the remaining half, Halictidae represent almost a quarter (385 species), with Apidae (197 species), Megachilidae (168 species) and the Australian endemic Stenotritidae (21 species) comprising the remaining quarter. New Zealand also contains a high proportion of Colletidae, comprising two thirds (28 of 40 species) of the recognized bee species. Halictidae, Megachilidae and Apidae account for the remaining third with five, five and three species, respectively (Donovan 1983). Of the 40 total species, eight were deliberate exotic bee introductions to aid crop pollination, including four bumblebee (Bombus) species (Howlett and Donovan 2010).

\subsection{New Guinea}

New Guinea exhibits a similar family representation to Australia. Given the history of the landmasses' frequent connection, this is not surprising (Smith et al. 1994; Hall 2009). Michener (1965) notes that of the 40 groups of bees known from New Guinea, only six are not found in Australia, although this is largely based on the original descriptions by Friese (1909). Colletidae represent 109 of the 230 described species, including many Palaeorhiza, with Halictidae (55 species), Megachilidae (34 species) and Apidae (32 species) making up the remaining half (Friese 1909; Cheesman 1948; Michener 1980; Hirashima 1988). Pauly (1986) investigated the Halictidae of the region and described 21 new species of the Lasioglossum subgenus Homalictus. Despite much of New Guinea being inaccessible, his study highlights the impact that thorough sampling can have on known species diversity.

\subsection{Solomon Islands}

The bee fauna of the Solomon Islands was first summarised by Cockerell (1911), but the 

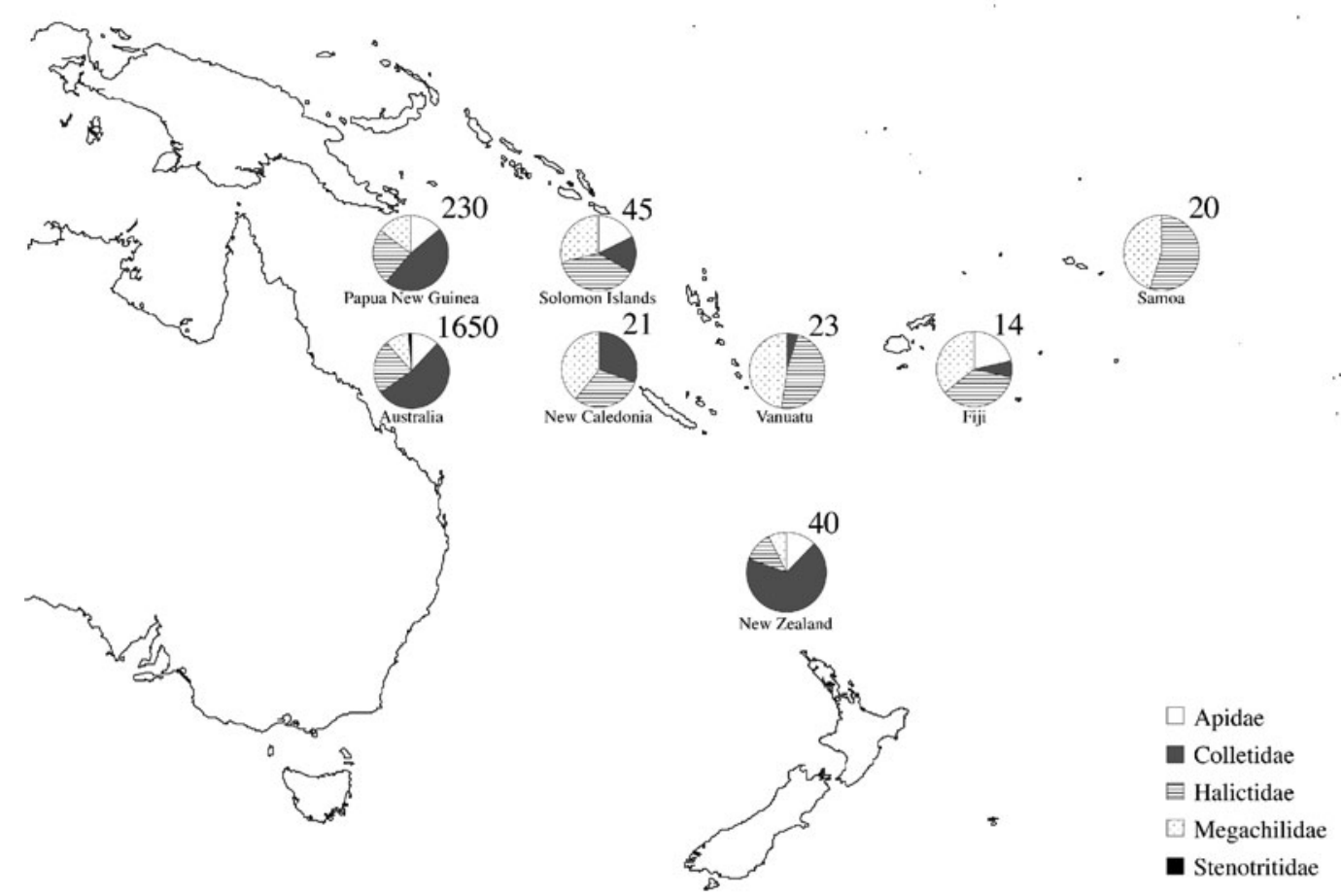

Figure 1. Map of the Southwest Pacific showing total species number and proportions of bee family representation for each island group.

first descriptions were completed by Krombein (1949, 1951) and Pauly (1984). Despite the close proximity of the Solomon Islands to New Guinea, bee family representation shares a closer affinity with Vanuatu (Pauly and Munzinger 2003). Halictidae (17 species) and Megachilidae (13 species) comprise two thirds of the 45 species, with Apidae (eight species) and Colletidae (seven species) accounting for the remaining third. However, since these earlier descriptions, there have been few studies on native bee fauna of the region, with the exception of Pauly (1986).

\subsection{New Caledonia}

A comparative study of New Caledonia and New Zealand bee fauna confirmed a much lower species richness in the former, with distinct differences in species representation of Colletidae, Halictidae and Megachilidae (Donovan 1983). Recently, the species of New Caledonia were reported by Pauly and Munzinger (2003) as comprising 21 species, consisting of eight species of Megachilidae, seven species of Halictidae and six species of Colletidae, although the authors noted that their study was far from exhaustive. Two new Lasioglossum species were described, Lasioglossum (Homalictus) cocos and Lasioglossum (Chilalictus) delobeli, both collected from nonnative angiosperm species. An undetermined Hylaeus species collected by Pauly and Munzinger (2003) is interesting in that along with Hylaeus fijiensis of Fiji, it comprises the only records for the genus in the SWP islands. 


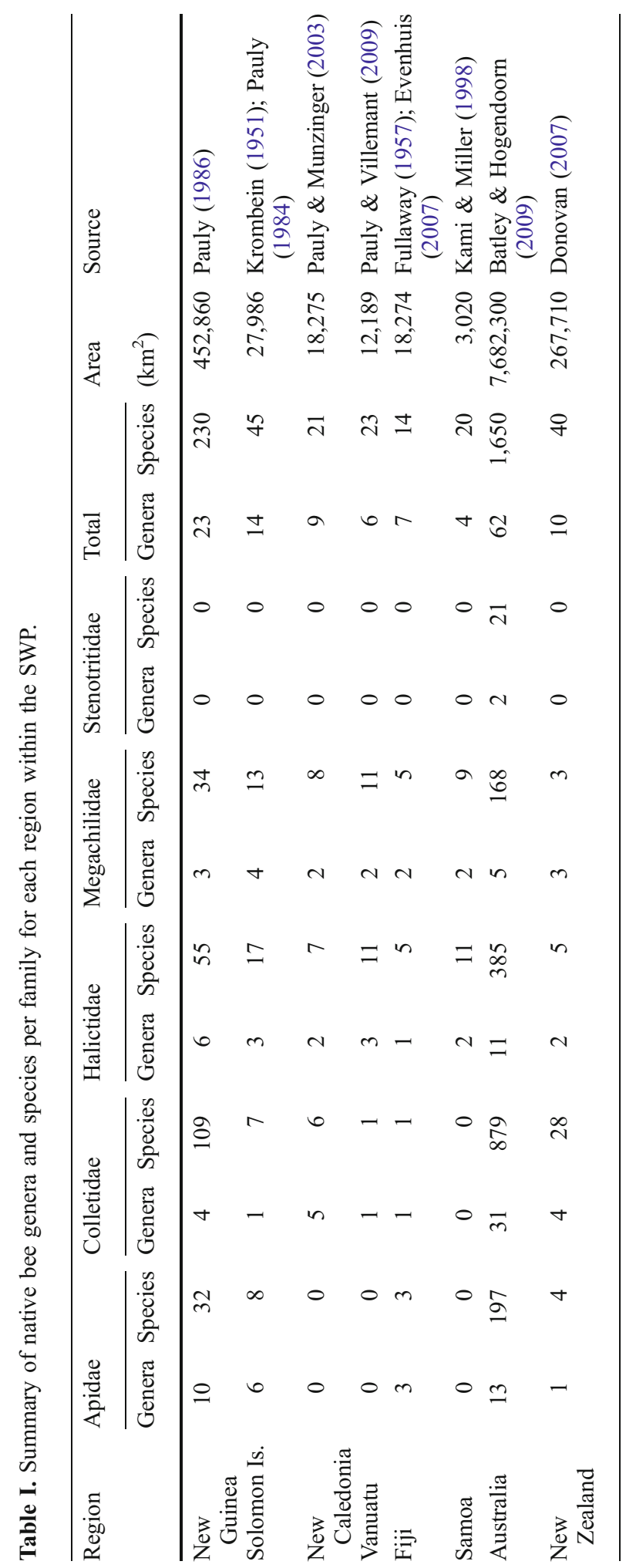




\subsection{Vanuatu}

Cockerell (1916) was among the first to investigate the bee fauna of Vanuatu, followed by Cheesman $(1936,1948)$ and Perkins and Cheesman (1939). Until recently, these descriptions remained the predominant studies of the bee fauna for this group. The survey of Vanuatu by Pauly and Villemant (2009) is of the most recent bee-focussed studies conducted in the SWP. Their survey brought the total bee fauna of Vanuatu to approximately 23 species, doubling the previously known number of species. Included in the survey were two newly described species, namely Lasioglossum (Chilalictus) vanuatu and an Austronomia sp. from the northwestern island of Santo. Pauly and Villemant's (2009) study therefore raises the possibility that SWP bee biota may be of much greater diversity than suggested by current systematic accounts.

\subsection{Fiji}

According to Michener (1965), the described bee fauna of the Pacific islands declines rapidly as one moves eastwards from Fiji. The bee fauna of Fiji, although less speciose than that of Vanuatu and Samoa (21 and 20 species, respectively), comprises 14 species from three families: Halictidae, Megachilidae and a single representative of Colletidae (Evenhuis 2007). As is common in the Pacific, Megachile and the Lasioglossum subgenus Homalictus represent the majority of Fijian records. Outside of these genera though, a number of Fijian species records could possibly represent human-induced dispersal such as the Indian allodapine bee Braunsapis puangensis, the Pacific-wide distributed Lithurgus scabrosus and Amegilla sp. (likely to be Amegilla sapiens from the Solomon Islands or Amegilla zonata of Indo-Australia).

\subsection{Samoa}

Kami and Miller (1998) recorded a total 20 non-Apis bee species from Samoa. As is the case in Fiji, the majority of this diversity consists of the genera Lasioglossum and Megachile, with ten and seven species, respectively. Within Samoan Lasioglossum, the 'explosive' endemism seen in Homalictus has been likened to the 60 species of Hylaeus in Hawaii (Krombein 1950; Magnacca and Danforth 2006). Samoa also harbours putative social parasites in this subgenus (Michener 1965) which, due to their highly modified structure and characteristics, Perkins and Cheesman (1928) originally placed in a separate genus Echthralictus. A phylogenetic study of Halictidae by Danforth et al. (2008) placed Homalictus, and presumably Echthralictus, within Lasioglossum.

The bee taxa of the Pacific, considered as a whole, reveals some interesting patterns, particularly the high representation of Halictidae and Megachilidae, as seen in Table I. Three genera-Lasioglossum, Megachile and, to a lesser extent, Lithurgus - contain the majority of species represented. Lasioglossum exhibits a high rate of endemism throughout the region, whilst the species of Megachilidae often appear to span numerous island groups. With the high proportion of species represented by these two families, evidence for the roles of vicariance versus dispersal is, therefore, likely to comprise multiple clades.

\section{PACIFIC BIOGEOGRAPHY}

Biogeographic histories in the Pacific have been the subject of much debate (e.g. Heads 2008, 2010b; Murienne 2010). This is not surprising given the complex breakup of eastern Gondwanan fragments combined with high volcanic activity for this region. As the Australian plate began rafting north during the Middle Cretaceous, it met the Pacific plate moving west, causing fragmentation and resulting in a series of basins, plateaus, island arcs and foredeeps (Raven and Axelrod 1972). New Guinea, New Caledonia and New Zealand represent examples of such complexity in that they consist of mosaics fused from island arcs, sections of ocean floor and seamounts of either Gondwanan or Central Pacific origin (Heads 2008, 2010a) from the Mesozoic, Paleozoic and probably older (Raven and Axelrod 1972). The 
Solomon Islands, Vanuatu, Fiji and Tonga are more recent and are thought to have once belonged to a continuous island arc, the Vitiaz Arc, before rifting apart (Heads 2008). Due to these vastly different tectonic histories, there are considerable biogeographical differences between some island groups. For example, despite being separated by only $200 \mathrm{~km}$, the Loyalty Islands of New Caledonia and southern Vanuatu exhibit major differences in some plant communities (Heads 2010a). Further illustrating the challenges involved in understanding SWP diversity are the island chains east of Fiji. Previously thought to be the result of mantle plume hot spots, they are now believed to be the result of stress-induced propagating fissures (Heads 2010a). Such circumstances open new niches in progressive chains that enable species to disperse relatively small distances rather than hot spots emerging at random location along seams.

The question of species' origins through vicariance or dispersal has been disputed for a range of marine and terrestrial taxa (de Queiroz 2005). The complex geological history of the Pacific, particularly in the Southwest, means that this issue has not been conclusively resolved for this region. Keppel et al. (2008) showed that genetic similarity in a broadly distributed group of SWP cycads (subsection Rumphiae) revealed a likely recent oceanic dispersal rather than vicariance. In contrast, Heads (2008) presented vicariance arguments for a number of patterns that were previously thought to comprise 'dispersal' examples, including the Australia/Pacific Lotus australis complex, focused around New Caledonia and the SWP. However, Grandcolas et al. (2008) provide support for an Eocene submersion of the entire New Caledonian land mass and suggest that the biota of the island can be no older than the Oligocene. However, Heads (2010a) argues that Pacific island taxa might be better considered as meta-populations where dispersal occurs among populations and vicariance between meta-populations. If an island population is assumed to have originated through founder speciation, rather than being considered within a meta-population, the age and origin of the species could be grossly misinterpreted. If the biota of New Caledonia is considered as part of such a meta-population, there may, therefore, be support for Pacific taxa older than the Oligocene. The possibility of dispersal back to New Caledonia from other islands in the region is admitted by Grandcolas et al. (2008); however, the authors doubt the existence of nearby islands that would meet the requirements, and their argument against vicariance is supported by numerous examples of molecular dating that suggest an Oligocene or younger origin.

In more recent times, anthropogenic dispersal has become a major factor in the transport of species between islands. The Melanesian islands have been inhabited since the Pleistocene, followed by Polynesia (Allen et al. 1988), with the first European settlements establishing trade routes during the last 150 years (Rolett and Diamond 2004). The origin of some taxa groups therefore requires thorough consideration, particularly where continental drift may precede species' origin. The literature has many cases of bee faunal distributions affected by human introductions. Perkins and Cheesman (1928) suggest that a considerable number of species in Samoa are unlikely to belong to the natural fauna and instead represent accidental importation. They also suggest that L. scabrosus, which is widespread through the Pacific including Hawai'i, was brought to the more isolated island group since its occupation by Europeans. The Indian allodapine bee B. puangensis, which is also found in Fiji (Evenhuis 2007; Ascher and Pickering 2010), is also likely to be introduced via human activity. Examples of anthropogenic dispersal of bees have been found in other areas of high trade routes in the world. Rehan et al. (2010) concluded that the widely distributed Asian species Neoceratina dentipes, found on the Indian Ocean island of Mauritius, is likely to be the result of heavy historic trade traffic rather than long-distance dispersal. Moreover, the wide distribution within the Indian Ocean of the wood-nesting bee Lithurgus pullatus is unlikely to have occurred 
solely through vegetation rafting (Pauly et al. 2001; Eardley et al. 2009).

The species $H$. fijiensis, also Fijian, represents an interesting radiation, whether human-induced or not. The species has been recorded numerous times from the Fijian islands (Cockerell 1909; Turner 1919; Fullaway 1957; Evenhuis 2007), yet remains unrecorded in other southern Pacific islands despite the genus having diversified rapidly in the northern Pacific (Magnacca and Danforth 2006).

Our current understanding of Pacific native bee fauna is limited because the majority of surveys occurred at the start of last century, and these were mostly descriptive, fragmented or not bee-specific (Turner 1918; Perkins and Cheesman 1928; Cockerell 1939; Fullaway 1957; Michener 1979a; Evenhuis 2007). Nevertheless, hypotheses on the biogeography of native bees in the Pacific have been numerous. The 60 species of Hylaeus of Hawai'i, the only bees native to the island group, form a single clade thought to have diversified from a single coloniser some 0.5 Mya that expanded into open niches (Magnacca and Danforth 2006). The recent volcanic origin and isolation of the island group, in addition to the closest relatives to the subgenus predominantly in Japan, but also China and Europe, provides support for long-distance dispersal ability in small bees. Long-distance oceanic dispersal has been demonstrated outside of the Pacific, having occurred multiple times from Africa to Madagascar within the last 50 million years via rafting and wind dispersion across the 450-km-wide Mozambique Channel (Fuller et al. 2005; Rehan et al. 2010). Moreover, Schwarz et al. (2006) have proposed island hopping across the Indian Ocean as a possible hypothesis for the African origin of Australian exoneurines given the lack of taxa in the Palearctic or Asia. However, Chenoweth and Schwarz (2011) propose that the timing of this origin is likely to have required dispersal via Antarctica, with subsequent diversification of temperate-adapted lineages.

The depauperate bee fauna of the SWP is puzzling given the age and locations of continental, and some volcanic, islands that have provided obvious historical routes of passage. The small number of bee species recorded from the SWP, in contrast to the diversification of Hylaeus in Hawaii, raises important questions about the factors that facilitate or inhibit bee radiations in island habitats. This highlights the need for a reconstruction of phylogenetic relationships between the islands' fauna to reveal possible dispersal corridors and the likely ages of origin for the major groups in relation to geological history. This understanding will provide important support for future conservation efforts through species identification and resolving taxonomic uncertainty, reconstructing relationships between island fauna, and with further potential for detecting populations in decline (Zayed 2009).

\section{THREATS TO BEES IN THE SOUTHWEST PACIFIC}

With increasing evidence of pollinator declines across the world (Kearns 2001; Warren et al. 2001; Williams et al. 2001; Biesmeijer et al. 2006; Potts et al. 2010), there is a critical need to understand the complexity of ecosystem interactions and how to best mitigate potential threats of disruption. In the SWP, drivers for these declines will probably share similarities with other regions. Habitat loss and fragmentation, agrochemicals, pathogens, alien species and climate change can potentially impact individually, but it is the interaction of drivers that can be most severe (Potts et al. 2010). Much of the world's threatened biodiversity exists in small island populations that are particularly susceptible to changes in habitat and disruption of system interactions (Kaiser-Bunbury et al. 2010). Therefore, the conservation of bees of the SWP, and the ecosystem services they provide, will rely on the understanding of how to best manage impending changes.

Habitat loss is the most influential driver of bee diversity decline (Brown and Paxton 2009). Increasing agricultural intensification in the SWP is likely to be one of the biggest causes of habitat loss in the region. Inefficiency of agricultural management practices in the region 
may also expose populations to improper herbicide and pesticide use, although it is difficult to separate low bee densities due to large-scale agriculture (Batley and Hogendoorn 2009). Land clearing for agriculture, timber and food has occurred in the SWP since human colonisation of Melanesia nearly 3,000 years ago; however, recent intensification during the last 150 years has further accelerated this impact, leaving predominantly inaccessible habitat intact (Nunn 1990). Preventing further removal of primary and secondary forest, with increasing agricultural efficiency, will be one key to controlling further habitat loss.

The introduction of exotic species to island groups has been a large part of recent SWP history since the intercontinental trade of European contact (Cox and Elmqvist 2000). Exotic plant species have the potential to invade and erode native mutualistic pollination webs (Aizen et al. 2008). Conversely, they may provide a foraging resource in developed areas should they produce sufficient quality and quantity of pollen and nectar (Stout and Morales 2009). However, it is the current threat from alien invertebrates that have the potential to decimate pollinator populations. The Asian honeybee Apis cerana is an aggressive invasive species that has become a significant threat to pollination services in recent times (De Barro 2007). Not only does this species pose a threat in terms of resource competition, but as a primary host of the Varroa mite, it also provides a vector for transmission of the parasite (Anderson and Trueman 2000). In the Solomon Islands, the impact of this is already evident with reports of approximately 2,000 managed Apis mellifera honeybee decimated (Anderson 2010). With established apicultural industries on most major islands, in addition to feral populations, both the economies and ecosystems of the SWP could be impacted heavily. It is therefore imperative that native bee populations that are not known to be affected by such parasites and diseases are managed as potentially critical pollinators in the event of honeybee population collapse.

The extrinsic factors of population declines discussed above are important threats to extinc- tion. However, in bees, which are haplodiploid, these factors have far more potential to drive extinction than in diploid organisms. Zayed and Packer (2005) showed that due to single-locus complementary sex determination (CSD) in Hymenoptera, small populations can have reduced CSD allelic richness, resulting in the production of excess sterile diploid males that can drive populations to extinction. In the SWP, there is potential for small, vulnerable populations of 'cryptic' Lasioglossum species given their extensive morphological intraspecies variation (Perkins and Cheesman 1939). However, Zayed et al. (2007) were able to show that despite severe genetic load and small founding populations, Lasioglossum leucozonium managed to spread and persist in North America for over a century. Schmid-Hempel et al. (2007) demonstrated a similar situation in the establishment of the bumblebee Bombus terrestris in Tasmania and New Zealand, albeit detrimental to native bee populations (Goulson et al. 2002; Goulson 2003). The mechanisms underlying this may reveal how the extant bee fauna of the SWP was able to colonise islands and persist whilst at the same time illustrate the fragility of populations to extinction.

Overarching these threats of bee population decline is the threat posed by climate change scenarios. If the threat of multiple drivers of population decline is considered under climate change, where ecosystem interactions may be heavily disrupted (Schweiger et al. 2010), the threats to smaller island populations are greatly increased. Climate change has the potential to impact bee biodiversity at all levels from individual fitness to community interactions (Gilman et al. 2010). However, a lack of baseline data for the majority of bee species in the SWP, and indeed across the globe, limits our understanding of species' climate envelopes and how climate change will impact all aspects of bee life cycles (Brown and Paxton 2009). However, some impacts have already been measured in changes to species distribution, such as British bumblebees (Williams et al. 2007), and in temporal shifts in flowering period affecting plant-pollinator relationships 
(Thomson 2010). The threat of alien colonisation, establishment and survival is also expected to increase with previously inhibiting environmental factors reduced under climate change, although exactly how these invasion will alter ecosystems is unknown (Walther et al. 2009). Underlying such direct impacts are the indirect effects of climate change on species interactions (Potts et al. 2010), which are critical for ecosystem function as opposed to just species diversity (Kaiser-Bunbury et al. 2010). Given this, adaptation to climate change impacts in the SWP will be difficult to manage and monitor without the required baseline data.

\section{CONSERVATION OF NATIVE BEES IN THE SOUTHWEST PACIFIC}

One key to conserving native bees in the SWP involves knowledge of their current diversity. The majority of studies conducted in the region have been from visiting researchers, with limited concentration on bee collection and with limited transfer of knowledge to local communities. Encouraging local research, with increasing community awareness of local bee diversity, will be critical to the long-term sustainability of native bees in the region. Byrne and Fitzpatrick (2009) reviewed current global, regional and national policy frameworks triggered from documented declines in bee populations worldwide. Higher-tier initiatives are known to be effective in supporting impacts at a regional and national scale, although such integration in the SWP is still in its infancy. If available support is utilised, however, regional awareness and policy can be influenced. Methodology outlined for categorizing threatened species by the International Union for Conservation of Nature has been used successfully to produce bee Red Lists at both regional (Fitzpatrick et al. 2007) and national (Sarospataki et al. 2005) scales. Within the SWP, established communication networks through a number of groups (e.g. Secretariat of the Pacific Community (SPC), the developing Oceania Pollinator Initiative (OPI) and PACINET the regional division of Bio-NET) mean that similar results are very much attainable for this region.
The SWP is largely without baseline data, which limits the assessment of native bee populations. Monitoring threats to their persistence requires an understanding of current species' diversity, distribution and abundance. Cooperation with local experts will not only broaden the scope of such studies but will also provide a legacy to conservation in the region. Eardley et al. (2009) outline the effective support that local 'champions' can provide for research subjects. However, in the absence of mentoring from both local and foreign experts, many potential champions do not develop, and therefore, it is important to involve both young scientists and senior researchers. There is great potential in current research centres of the University of the South Pacific, in addition to the SPC and OPI, that would benefit greatly from collaboration with global research programmes to produce foundation studies.

Integration of local research with studies of wider bee ecology is important for not only ensuring long-term collaboration but also in aiding support of research by modern tools such as barcoding and other molecular tools (Sheffield et al. 2009). Genetic analyses, which have often been financially restrictive in the past, can now be outsourced at low cost without the need for expensive local facilities. These tools are important for revealing potentially very recent speciation in the SWP where morphologybased studies may not reveal recent and ongoing diversification, which may in turn be important for establishing conservation priorities in the SWP (Myers et al. 2000).

\section{CONCLUSIONS}

The SWP Pacific has a complex geological history that has shaped a diverse flora and fauna. Although current knowledge suggests a depauperate bee fauna, there is evidence for cryptic species and recent speciation events that may greatly augment current reckonings of diversity. Understanding the evolutionary history of bees in the SWP is important in establishing conservation priorities and will inform effective native bee population management in island groups. Pro- 
grammes such as the developing OPI will be important in increasing awareness of native bees as pollinators in the SWP, but they require ongoing research where results can be distributed through networks such as the SPC. International collaborations will be important in providing opportunities for further research, but sustainability of initiatives will ultimately rely on building regional capacity.

\section{ACKNOWLEDGEMENTS}

We thank Sandra Rehan and Luke Chenoweth for valuable comments on this work. We thank Marika Tuiwawa and the South Pacific Regional Herbarium at the University of the South Pacific, Mary Taylor, and Posa Skelton for their ongoing support of our project. SVCG and MPS were supported by grants from the Australian Pacific Science Foundation and National Climate Change Adaptation Research Facility.

Les abeilles dans le sud-ouest du Pacifique: origines, diversité et conservation.

\section{Abeilles / conservation / biodiversité / biogéog- raphie / région Pacifique}

\section{Bienen im Südwestpazifik: Herkunft, Diversität und Artenschutz}

\section{Bienen / Artenschutz / Biodiversität / Biogeog- raphie / Pazifik}

\section{REFERENCES}

Aizen, M.A., Morales, C.L., Morales, J.M. (2008) Invasive mutualists erode native pollination webs. Plos. Biol. 6, 396-403

Allen, J., Gosden, C., Jones, R., White, J.P. (1988) Pleistocene dates for the human occupation of NewIreland, Northern Melanesia. Nature 331, 707-709

Anderson, D.L. (2010) Control of Asian honeybees in the Solomon Islands, CSIRO Entomology Australia. http://aciar.gov.au/project/PC/2004/030 (25 November 2010)

Anderson, D.L., Trueman, J.W.H. (2000) Varroa jacobsoni (Acari: Varroidae) is more than one species. Exp. Appl. Acarol. 24, 165-189
Ascher, J.S., Pickering, J. (2010) World Checklist of Bees. www.discoverlife.org $/ \mathrm{mp} / 20 \mathrm{q}$ ? act $=\mathrm{x}$ _checklist\& guide=Apoidea_species (25 November 2010$)$

Batley, M., Hogendoorn, K. (2009) Diversity and conservation status of native Australian bees. Apidologie 40, 347-354

Biesmeijer, J.C., Roberts, S.P.M., Reemer, M., Ohlemuller, R., Edwards, M., Peeters, T., Schaffers, A.P., Potts, S. G., Kleukers, R., Thomas, C.D., Settele, J., Kunin, W. E. (2006) Parallel declines in pollinators and insectpollinated plants in Britain and the Netherlands. Science 313, 351-354

Brown, M.J.F., Paxton, R.J. (2009) The conservation of bees: a global perspective. Apidologie 40, 410-416

Byrne, A., Fitzpatrick, Ö. (2009) Bee conservation policy at the global, regional and national levels. Apidologie 40, 194-210

Cheesman, L.E. (1936) Hymenoptera of the New Hebrides and Banks Islands. Trans. R. Entomol. Soc. London 85, 169-195

Cheesman, L.E. (1948) Bees of New Guinea and the New Hebrides. Ann. Mag. Nat. Hist. 12, 318-335

Chenoweth, L.B., Schwarz, M.P. (2011) Biogeographical origins and diversification of the exoneurine allodapine bees of Australia (Hymenoptera, Apidae), J. Biogeogr 38, 1471-1483

Cockerell, T.D.A. (1909) Descriptions and records of bees-XXIII. Ann. Mag. Nat. Hist. 4, 393-404

Cockerell, T.D.A. (1911) The bees of the Solomon Islands. Proc. Linn. Soc. New South Wales 36, 160-178

Cockerell, T.D.A. (1916) Some bees from Australia, Tasmania, and the New Hebrides. Proc. Acad. Nat. Sci. Philadelphia 68, 360-375

Cockerell, T.D.A. (1939) XII-Descriptions and records of bees-CLXXV. J. Nat. Hist. Series 11 4, 185-192

Cox, P.A., Elmqvist, T. (2000) Pollinator extinction in the Pacific Islands. Conserv. Biol. 14, 1237-1239

Danforth, B.N., Eardley, C., Packer, L., Walker, K., Pauly, A., Randrianambinintsoa, F.J. (2008) Phylogeny of Halictidae with an emphasis on endemic African Halictinae. Apidologie 39, 86-U42

De Barro, P. (2007) The future of the Australian Honeybee Industry. CSRIO Entomology 1-18

de Queiroz, A. (2005) The resurrection of oceanic dispersal in historical biogeography. Trends Ecol. Evol. 20, 68-73

Donovan, B.J. (1983) Comparative biogeography of Native Apoidea of New Zealand and New Caledonia. GeoJournal 7, 511-516

Donovan, B.J. (2007) Apoidea (Insecta: Hymenoptera). Fauna of New Zealand 57, 295

Eardley, C.D., Gikungu, M., Schwarz, M.P. (2009) Bee conservation in Sub-Saharan Africa and Madagascar: diversity, status and threats. Apidologie 40, 355-366

Evenhuis, N.L. (2007) Checklist of Fiji Hymenoptera, Bishop Museum Techn. Rep. 38 
Fitzpatrick, U., Murray, T.E., Paxton, R.J., Brown, M. J.F. (2007) Building on IUCN regional red lists to produce lists of species of conservation priority: a model with Irish bees. Conserv. Biol. 21, 13241332

Friese, H. (1909) Die Bienenfauna von Neu-Guinea, Annales historico-naturales Musei Nationalis Hungarici (Termeszettudomanyi Muzeum evkonyve) 7 , 179-288

Fullaway, D.T. (1957) Checklist of Hymenoptera of Fiji. Proc. Haw. Entomol. Soc. 16, 269-280

Fuller, S., Schwarz, M., Tierney, S. (2005) Phylogenetics of the allodapine bee genus Braunsapis: historical biogeography and long-range dispersal over water. J. Biogeogr. 32, 2135-2144

Gilman, S.E., Urban, M.C., Tewksbury, J., Gilchrist, G. W., Holt, R.D. (2010) A framework for community interactions under climate change. Trends Ecol. Evol. 25, 325-331

Goulson, D. (2003) Effects of introduced bees on native ecosystems. Annual Review of Ecology Evol. Syst. 34, 1-26

Goulson, D., Stout, J.C., Kells, A.R. (2002) Do exotic bumblebees and honeybees compete with native flower-visiting insects in Tasmania?, J. Insect Conserv. 6, 179-189

Grandcolas, P., Murienne, J., Robillard, T., DesutterGrandcolas, L., Jourdan, H., Guilbert, E., Deharveng, L. (2008) New Caledonia: A very old Darwinian island?. Philos. Trans. R. Soc. B-Biological Sciences 363, 3309-3317

Hall, R. (2009) Southeast Asia's changing palaeogeography. Blumea 54, 148-161

Heads, M. (2008) Panbiogeography of New Caledonia, south-west Pacific: basal angiosperms on basement terranes, ultramafic endemics inherited from volcanic island arcs and old taxa endemic to young islands. J. Biogeogr. 35, 2153-2175

Heads, M. (2010a) Biogeographical affinities of the New Caledonian biota: a puzzle with 24 pieces. J. Biogeogr. 37, 1179-1201

Heads, M. (2010b) New Caledonian biogeography: a reply to Murienne. J. Biogeogr. 37, 1627-1627

Hirashima, Y. (1988) Bees of the Genus Palaeoreziza Perkins (Hymenoptera, Colletidae) of Papua New Guinea collected by the Kyushu University Expedition. Esakia 26, 5-19

Howlett, B.G., Donovan, B.J. (2010) A review of New Zealand's deliberately introduced bee fauna: current status and potential impacts. N. Z. Entomol. 33, 92101

Kaiser-Bunbury, C.N., Traveset, A., Hansen, D.M. (2010) Conservation and restoration of plantanimal mutualisms on oceanic islands. Perspect. Plant Ecol. 12, 131-143

Kami, K.S., Miller, S.E. (1998) Samoan insects and related arthropods: Checklist and bibliography
Kearns, C.A. (2001) North American dipteran pollinators: assessing their value and conservation status. Conserv. Ecol. 5, 5

Keppel, G., Hodgskiss, P.D., Plunkett, G.M. (2008) Cycads in the insular South-west Pacific: dispersal or vicariance?, J. Biogeogr. 35, 1004-1015

Kohl, F. (1908) Hymenopteren, in: Rechinger K. (Ed) Botanische und zoologische Ergebnisse einer wissenschaftlichen Forschungsreise nach den Samoa-Inseln, dem Neuguinea-Archipel und den Salomons-Insel, Denkschriften der Kaiserlichen Akademie der Wissenschaften, Mathematisch-Naturwissenschaftliche Klasse, pp. 306-317

Krombein, K.V. (1949) Records of Bees from the Solomon Islands with Descriptions of New Subspecies (Hymenoptera, Apoidea). Bull. Brooklyn Entomol. Soc. 44, 10-14

Krombein, K.V. (1950) The aculeate Hymenoptera of Micronesia II. Colletidae, Halictidae, Megachilidae, and Apidae. Proc. Hawaii. Entomol. Soc. XIV, pp. 101-142

Krombein, K.V. (1951) Additional notes on the bees of the Solomon Islands (Hymenoptera: Apoidea). Proc. Hawaii. Entomol. Soc. XIV, pp. 277-295

Magnacca, K.N., Danforth, B.N. (2006) Evolution and biogeography of native Hawaiian Hylaeus bees (Hymenoptera: Colletidae). Cladistics 22, 393-411

Michener, C.D. (1965) A Classification of the Bees of the Australian and South Pacific Regions. Bull. Am. Mus. Nat. Hist. 130, 1-362

Michener, C.D. (1979a) Biogeography of the Bees. Ann. Missouri Bot. Gard. 66, 277-347

Michener, C.D. (1979b) Genus Homalictus in Fiji (Hymenoptera, Halictidae). Pac. Insects 21, 227-234

Michener, C.D. (1980) The large species of Homalictus and related Halictinae from the New Guinea area (Hymenoptera, Apoidea). Am. Mus. Novitates 2693, $1-21$

Murienne, J. (2010) Panbiogeography of New Caledonia: a response to Heads (2008). J. Biogeogr. 37, 1626-1626

Myers, N., Mittermeier, R.A., Mittermeier, C.G., da Fonseca, G.A.B., Kent, J. (2000) Biodiversity hotspots for conservation priorities. Nature 403, 853-858

Nunn, P.D. (1990) Recent environmental changes on Pacific Islands. Geogr. J. 156, 125-140

Pauly, A. (1984) Les Homalictus Cockerell (Hymenoptera Apoidea Halictidae) de l'ile Rennell (Iles Salomons), Copenhagen

Pauly, A. (1986) Les Abeilles de la Sous-Famille des Halictinae en Nouvelle-Guinee et Dans Larchipel Bismarck (Hymenoptera: Apoidea: Halictidae). Zool. Verh. 227, 3-58

Pauly, A., Brooks, W., Nilsson, L.A., Persenko, Y.A., Eardley, C.D., Terzo, M., Griswold, T., Schwarz, M. P., Patiny, S., Munzinger, J., Barbier, Y. (2001) 
Hymenoptera Apoidea de Madagascar. Ann. Zool. Wet. 128, 1-390

Pauly, A., Munzinger, J. (2003) Contribution à la connaissance des Hymenoptera Apoidea de Nouvelle-Calédonie et de leurs relations avec la flore butinée. Ann. Soc. Entomol. Fr. 39, 153-166

Pauly, A., Villemant, C. (2009) Hyménoptères Apoidea (Insecta) de l'archipel du Vanuatu. Zoosystema 31, 719-730

Perkins, R.C.L., Cheesman, L.E. (1928) HymenopteraApoidea, Sphecoidea, and Vespoidea, Insects of Samoa Part V., pp. 1-32

Perkins, R.C.L., Cheesman, L.E. (1939) Halictine bees from the New Hebrides and banks islands. Trans. R. Entomol. Soc. Lond. 88, 161-171

Potts, S.G., Biesmeijer, J.C., Kremen, C., Neumann, P., Schweiger, O., Kunin, W.E. (2010) Global pollinator declines: trends, impacts and drivers. Trends Ecol. Evol. 25, 345-353

Raven, P.H., Axelrod, D.I. (1972) Plate Tectonics and Australasian Paleobiogeography. Science 176, 13791386

Rehan, S.M., Chapman, T.W., Craigie, A.I., Richards, M. H., Cooper, S.J.B., Schwarz, M.P. (2010) Molecular phylogeny of the small carpenter bees (Hymenoptera: Apidae: Ceratinini) indicates early and rapid global dispersal. Mol. Phylogenet. Evol. 55, 1042-1054

Rolett, B., Diamond, J. (2004) Environmental predictors of pre-European deforestation on Pacific islands. Nature 431, 443-446

Sarospataki, M., Novak, J., Molnar, V. (2005) Assessing the threatened status of bumble bee species (Hymenoptera : Apidae) in Hungary, Central Europe. Biodivers. Conserv. 14, 2437-2446

Schmid-Hempel, P., Schmid-Hempel, R., Brunner, P.C., Seeman, O.D., Allen, G.R. (2007) Invasion success of the bumblebee, Bombus terrestris, despite a drastic genetic bottleneck. Heredity 99, 414-422

Schwarz, M.P., Fuller, S., Tierney, S.M., Cooper, S.J.B. (2006) Molecular phylogenetics of the exoneurine allodapine bees reveal an ancient and puzzling dispersal from Africa to Australia. Syst. Biol. 55, 31-45

Schweiger, O., Biesmeijer, J.C., Bommarco, R., Hickler, T., Hulme, P.E., Klotz, S., Kuhn, I., Moora, M., Nielsen, A., Ohlemuller, R., Petanidou, T., Potts, S.G., Pysek, P., Stout, J.C., Sykes, M.T., Tscheulin, T., Vila, M., Walther, G.R., Westphal, C., Winter, M., Zobel, M., Settele, J. (2010) Multiple stressors on biotic interactions: how climate change and alien species interact to affect pollination. Biol. Rev. 85, 777-795

Sheffield, C.S., Hebert, P.D.N., Kevan, P.G., Packer, L. (2009) DNA barcoding a regional bee (Hymenoptera: Apoidea) fauna and its potential for ecological studies. Mol. Ecol. Resour. 9, 196-207
Smith, A.G., Smith, D.G., Funnell, B.M. (1994) Atlas of Mesozoic and Cenozoic coastlines, Cambridge University Press, Cambridge

Smith, F. (1879) Descriptions of new species of Hymenoptera in the collection of the British Museum, London

Smith, F. (1953) Catalogue of Hymenopterous Insects in the Collection of the British Museum, London

Stout, J.C., Morales C.L. (2009) Ecological impacts of invasive alien species on bees. Apidologie 40, 388409

Thomson, J.D. (2010) Flowering phenology, fruiting success and progressive deterioration of pollination in an early-flowering geophyte. Philos. Trans. R. Soc. B-Biological Sciences 365, 3187-3199

Turner, RE. (1918) On the Hymenoptera collected in New Caledonia by P.D. Montague in 1914. Ann. Mag. Nat. Hist. 3, 229-240

Turner, R.E. (1919) The Hymenoptera of Fiji. Trans. R. Entomol. Soc. Lond. 66, 334-346

Walther, G.R., Roques, A., Hulme, P.E., Sykes, M.T., Pysek, P., Kuhn, I., Zobel, M., Bacher, S., BottaDukat, Z., Bugmann, H., Czucz, B., Dauber, J., Hickler, T., Jarosik, V., Kenis, M., Klotz, S., Minchin, D., Moora, M., Nentwig, W., Ott, J., Panov, V.E., Reineking, B., Robinet, C., Semenchenko, V., Solarz, W., Thuiller, W., Vila, M., Vohland, K., Settele, J. (2009) Alien species in a warmer world: risks and opportunities. Trends Ecol. Evol. 24, 686-693

Warren, M.S., Hill, J.K., Thomas, J.A., Asher, J., Fox, R., Huntley, B., Roy, D.B., Telfer, M.G., Jeffcoate, S., Harding, P., Jeffcoate, G., Willis, S.G., Greatorex-Davies, J.N., Moss, D., Thomas, C.D. (2001) Rapid responses of British butterflies to opposing forces of climate and habitat change. Nature 414, 65-69

Williams, N.M., Minckley, R.L., Silveira, F.A. (2001) Variation in native bee faunas and its implications for detecting community changes. Conserv. Ecol. 5, 1-24

Williams, P.H., Araujo, M.B., Rasmont, P. (2007) Can vulnerability among British bumblebee (Bombus) species be explained by niche position and breadth?. Biol. Conserv. 138, 493-505

Zayed, A. (2009) Bee genetics and conservation. Apidologie 40, 237-262

Zayed, A., Constantin, S.A., Packer, L. (2007) Successful Biological Invasion despite a Severe Genetic Load. Plos One 2, 1-6

Zayed, A., Packer, L. (2005) Complementary sex determination substantially increases extinction proneness of haplodiploid populations. Proc. Nat. Acad. Sci. USA 102, 10742-10746 